\title{
PEMANFAATAN PROGRAM GENERASI SEHAT CERDAS TERHADAP PROSES PENGEMBANGAN PENDIDIKAN DAN KESEHATAN MASYARAKAT DI DESA GENTENG KECAMATAN SUKASARI SUMEDANG
}

\author{
Oleh: \\ Tomi Sapari, R. Nunung Nurwati, \& Maulana Irfan \\ E-mail : \\ tomi12001@student.unpad.ac.id, nngnurwati@yahoo.co.id, sangirfan@gmail.com
}

\begin{abstract}
ABSTRAK,
Pendidikan dan kesehatan merupakan hal yang mutlak yang harus dimiliki oleh masyarakat, begitu pula dengan masayarakat di Desa Genteng. Kesehatan memberikan kesempatan masyarakat untuk hidup lebih baik dan bisa menjaga pola hidup yang baik terutama kesehatan ibu dan anak. Karena ibu dan anak adalah kelompok yang rentan terkena gangguan penyakit. Kemudian dari segi pendidikan program PNPM Generasi Cerdas memberikan fasilitas kepada masyarakat yang mempunyai anakanak yang masih berada diusia sekolah yang berasal dari keluarga tidak mampu secara ekonomi agar bisa terus bersekolah dan menggapai cita-citanya. Pemerintah telah membuat program dan melaksanakannya, masyarakat sebagai penerima manfaat menggunakan haknya. Selian anak-anak tentunya orang tua mempunyai peranan penting untuk menyekolahkan anaknya ke tingkat yang paling tinggi. Program PNPM juga adalah pogram pemberdayaan masyarakat agar mereka mampu untuk mencari solusi dari permasalahan yang dialami, kemudian selain itu juga masyarakat mempunyai peluang dan potensi yang harus dikembangkan. Dari bidang kesehatan dengan meningkatkan kesadaran masyarakat akan pentingny kesehatan melalui kader-kader keluarga berencana yang bekerjasama dengan fasilitator desa mendata masyarakat yang rentan terhadap gangguan kesehatan dan melakukan imunisasi kepada balita. Selain itu juga pemberian pengetahuan kepada masyarakat tentang pola hidup sehat dengan menggunakan sumber daya alam yang ada di Desa Genteng.
\end{abstract}

Kata Kunci: Pendidikan, Kesehatan, Program PNPM, Masyarakat, dan Potensi

\begin{abstract}
Education and health is an absolute that must be owned by the community, as well as the community in the village of tiles. Health gives people the chance to live a better life and can maintain a good lifestyle, especially the health of mothers and children. Because women and children are the most vulnerable groups affected by disease. Then in terms of education PNPM Generation Intelligent provide facilities to people who have children who are still of school age who come from economically disadvantaged families in order to stay in school and reach his goals. The government has made the program and execute it, the people as beneficiaries exercise their rights. Selian children of course parents have an important role to send their children to the highest level. PNPM program also is pogram community empowerment so that they were able to find solutions to the problems
\end{abstract}


experienced, then it is also the public has the opportunity and potential to be developed. From the health sector by increasing public awareness of the pentingny health through family planning cadres in cooperation with village facilitators public records that are vulnerable to health problems and do immunizations to children. In addition, the provision of knowledge to the public about healthy lifestyles by using natural resources in the village tiles.

Keywords: Education, Health, PNPM program, Community, and Potency

\section{PENDAHULUAN}

Pendidikan merupakan usaha sadar yang dilakukan oleh individu, kelompok atau masyarakat untuk mempersiapkan diri agar dapat melaksanakan peran dan fungsinya dalam berbagai lingkungan dimasa yang akan datang Pendidikan merupakan hal yang paling penting dalam proses perkembangan individu dan masyarakat, dengan pendidikan manusia bisa merancang sebuah model masa depan yang lebih baik. Masyarakat desa memandang pendidikan merupakan hal yang penting, namun ketersediaan sistem sumber yang mendukungnya belum dapat terpenuhi. Terutama untuk masyarakat yang perekonomiannya menengah kebawah. Pendidikan dasar sembilan tahun yang digadang-gadang pemerintah bisa mengatasi masalah pendidikan. Pendidikan memuat gambaran tentang nilai-nilai yang baik, luhur, pantas, benar, dan indah untuk kehidupan. Karena itu tujuan pendidikan memiliki dua fungsi yaitu memberikan arah kepada segenap kegiatan pendidikan dan merupakan sesuatu yang ingin dicapai oleh segenap kegiatan pendidikan.

Rendahnya tingkat kesehatan dan pendidikan pada rumah-tangga miskin merupakan tantangan utama yang harus dihadapi Indonesia dalam rangka penanggulangan kemiskinan. Masih tingginya angka mortalitas balita serta rendahnya tingkat penyelesaian pendidikan dasar dan menengah pertama anak-anak dalam rumah tangga miskin, merupakan isu - isu strategis yang sangat berpotensi menghambat upaya penanggulangan kemiskinan di Indonesia. Tanpa disertai upaya peningkatan kesehatan dan pendidikan, terutama kepada anak-anak generasi mendatang yang hidup dalam setiap rumah-tangga miskin, upaya untuk mengurangi angka kemiskinan di Indonesia akan sulit dilakukan. Ditinjau dari sisi kebutuhan masyarakat serta pelayanan pendidikan dan kesehatan di Indonesia, ada beberapa masalah yang perlu menjadi perhatian. Pemerintah Indonesia tengah berupaya untuk mendorong percepatan penurunan kemiskinan melalui penguatan kembali program-program penanggulangan kemiskinan yang telah ada. Mulai tahun 2007, telah dicanangkan program nasional dalam rangka melanjutkan dan mengembangkan program penanggulangan kemiskinan yang disebut dengan Program Nasional Pemberdayaan Masyarakat Mandiri (PNPMMandiri). Melalui PNPM-Mandiri, pemerintah melanjutkan program penanggulangan kemiskinan yang telah berjalan baik seperti Program Pengembangan Kecamatan (PPK).

Kesehatan dan Pendidikan merupakan faktor utama yang penting dalam kehidupan masyarkat, dua hal tersebut tidak dapat dilepaskan dari proes keberlangsungan hidup manusia. Sehat adalah hal wajib yang harus dimiliki oleh masyarakat baik di masyarakat kota maupun masyarakat desa, tidak ada jaminan bahwa orang yang tinggal di kota akan memiliki tingkat kesehatan yang tinggi, begitu juga masyarakat desa belum tentu juga jaminan kesehatan. Yang membedakan adalah ketika masyarakat kota terganggu kesehatannya maka akses mereka ke lembaga kesehatan mudah, sedangkan masyarakat desa sedikit terhambat aksesnya ke sarana kesehatan. Gaya hidup sehat merupakan solusi terbaik bari permalasahan kesehatan yang terjadi di Indonesia, karena banyak orang yang 
meninggal karena mengalami gangguan kesehatan, salah satu diantaranya yang paling mematikan adalah penyakit jantung yang menempati peringkat pertama. Tantangannya adalah mengajak masyarakat untuk berpola hidup sehat, tidak hanya mengajak saja nemun juga harus disiapkan sarana dan prasarana kesehatan yang dapat diakses dengan mudah oleh masyarakat terutama masyarakat menengah kebawah.

Program generasi sehat dan cerdas ini telah dilaksanakan diberbagai wilayah indonesia termasuk diantaranya adalah Desa Genteng, di desa Genteng program ini telah berjalan dari tahun 2011 dimana tujuan program ini adalah membantu anak-anak yang sedang berada dalam usia sekolah yang masih sekolah. Program ini memberikan bantuan berupa uang kepada anak-anak tersebut untuk membeli perlengkapan sekolah seperti baju seragam, alat tulis, dan membeli buku bacaan. Untuk yang putus sekolah memiliki treatment tersendiri agar anak tersebut dapat bersekolah kembali.

Program ini merupakan bagian dari PNPM Mandiri yang direncanakan akan dilakukan sampai dengan tahun 2015. Pendekatan dalam PNPM Generasi dengan menggunakan dasar-dasar pemberdayaan masyarakat. Artinya bahwa program ini harus berangkat dari masyarakat, dilakukan oleh masyarakat dan diperuntukkan juga bagi masyarakat. Dibandingkan dengan pendekatan lainnya, pendekatan pemberdayaan masyarakat lebih mampu menjamin efektifitas dan keberlanjutan sebuah program penanggulangan kemiskinan. Hadirnya program ini juga sebagai pelengkap bantuan dana Bantuan Operasional Sekolah, namun jika bantuan BOS tersebut sasarannya hanya untuk pihak sekolah untuk membebaskan biaya pendidikan 9 tahun dari SD-SMP, namun belum menyasar ke siswanya. Sehingga adanya program ini anak-anak tersebut bisa tenang dalam melaksanakan kewajibannya sebagai pelajar untuk menuntut ilmu dengan baik.

\section{PEMBAHASAN}

Gambaran Umum Masyarakat

Desa Genteng merupakan Desa yang menarik dengan segala potensinya, potensi Sumder Daya Alamnya yang indah dan potensi Kearifan Budaya-nya yang tetap terjaga. Desa Genteng terletak di kecamatan Sukasari Kabupaten Sumedang, memiliki luas \pm 1300 Hektar dengan jumlah penduduk 6042 jiwa dengan jumlah 2087 KK yang tersebar pada enam dusun yang ada. Keadaan Sosial masyrakat Desa Genteng masih terlihat sangat kental, yakni masih adanya sifat kegotongroyongan masyarakat dalam berbagai kegiatan. Misalnya kegiatan kerja bakti sosial, pembangunan desa baik yang berasal dari perorangan maupun yang berasal dari program pemerintah sampai kepada pemerintahan desa yang sangat kental dengan nuansa kekeluargaannya.

Salah satu misi Desa Genteng dalam Rencana Pembangunan Jangka menengah Desa Genteng adalah pelestarian dan peningkatan sosial budaya masyarakat desa, yaitu dengan mewujudkan peningkatan dan pengembangan partisipasi masyarakat, kontrol sosial, tingkat kepercayaan masyarakat, hubungan berpemerintahan, serta hubungan sosial budaya masyarakat.

Sumber daya budaya Desa Genteng yang belum banyak dikenal oleh masyarakat menjadi kebalikan dari kenyataan bahwa begitu banyak potensi budaya yang ada di Desa Genteng serta perhatian pemerintah Desa terhadap potensi budaya ini. Dalam rangka melestarikan budaya sunda, di tengah segala keterbatasannya,

Desa Genteng konsisten melestarikan kearifan budaya seni tradisional yang sudah ada sejak dahulu. Delapan kelompok seni tradisional Desa Genteng tetap ada hingga sekarang menjadi bukti nyatanya. Belum lagi potensi kearifan kuliner lokal Desa Genteng sangat beragam dan unik serta tentunya berkualitas ditambah pemandangan alam Desa seakan melengkapi begitu eloknya Desa 


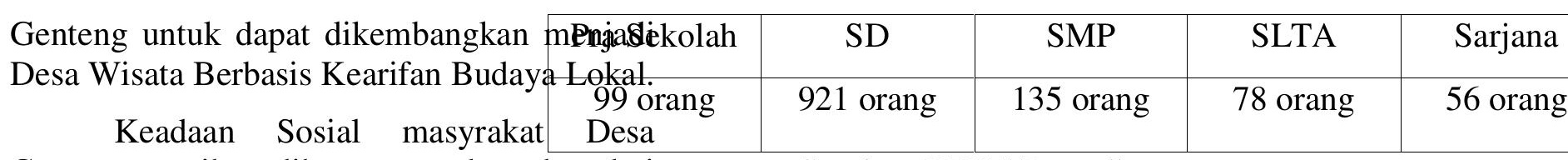

Genteng masih terlihat sangat kental, yakni masih adanya sifat kegotong-royongan masyarakat dalam berbagai kegiatan, namun potensi sumber daya manusia masyarakatnya masih belum dioptimalkan dengan baik. Beberapa potensi masyarakat Desa Genteng antara lain:

1. Banyaknya sarjana

2. Banyaknya tenaga kerja lulusan SLTA dan SLTP

3. Banyaknya tenaga ahli bidang pertanian dan peternakan

4. Banyaknya penggiat seni dan budaya

Dalam bidang agama, Desa Genteng terlihat lebih baik. Adanya dua pesantren yang terdapat di dua wilayah yakni Dusun Genteng dan Dusun Karangsari. Begitu pula dengan adanya TPA dan majeli ta'lim disetiap masjid di tiap wilayah dusun. Ini artinya kehidupan beragama Desa Genteng juga masih sangat kental.

Selanjutnya keaadaan sosial masyarakat bila dilihat dari dari segi pendidikan dapat dikategorikan baik. Dimana tingkat kesadaran orang tua untuk melanjutka pendidikan anaknya ke jenjang yang lebih tinggi sangat dominan.

Pendidikan adalah salah satu hal penting dalam memajukan tingkat kesejahteraan pada umumnya dan tingkat perekonomian pada khususnya. Pendidikan akan dapat mempertajam sistematika berpikir atau pola berpikir individu, selain itu mudah menerima informasi yang lebih maju. Dibawah ini tabel yang menunjukkan tingkat rata-rata pendidikan Desa Genteng.

Tabel 1

Tingkat Pendidikan Masyarakat Desa Genteng
Sumber: RPJM Desa Genteng

Selanjutnya untuk mata pencaharaian masyarakat Desa Genteng, umumnya bermatapencaharian sebagai petani dan peternak, sehingga keadaan ekonomi di Desa Genteng lebih didominasi dari hasil pertanian dan pertenakan. Dibawah ini tabel yang menunjujan mata pencaharian Masyarakat Desa Genteng

Tabel 2

Mata Pencaharian Masyakarat Desa Genteng

\begin{tabular}{|l|l|l|l|l|l|}
\hline Petani & Peternak & Buruh & PNS & $\begin{array}{l}\text { Pegawai } \\
\text { swasta }\end{array}$ & Pedagar \\
\hline 2856 orang & 1332 orang & 1002 orang & 68 orang & 76 orang & 305 Ora \\
\hline
\end{tabular}

Sumber: RPJM Desa Genteng

Desa genteng merupakan salah satu desa yang terletak di sebelah Barat Kabupaten Sumedang, yang termasuk dalam kecamatan Sukasari dimana kondisi geografisnya adalah pegunungan. Salah satu yang menjadi dasar alasan peneliti tertari untuk melakukan penelitian disana adalah tentang pendidikan, karena peneliti juga sebelumnya telah melakukan observasi melalui salah satu praktikum yang membahas tentang Indeks Pembangunan manusia yang didalamnya terdapat pendidikan sebagai indikator pembangunan manusia. Kemudian ada salah satu program yang dimana memfasilitasi anakanak sekolah untuk dapat mengakses pendidkan terutama mereka dari kalangan yang ekonominya tidak mampu, program tersebut dibawah naungan PNPM Mandiri. Program ini mengangkat pendidikan dan kesehatan sebagai tujuan yang harus diselesaikan permasalahannya.

Salah satu kebijakan pemerintah melaui PNPM mandiri Pesesaan yang bernama Generasi Sehat dan Cerdas, program ini 
memberikan fasilitas kepada masyarakat dalam rangka perencanaan dan pelaksanaan kegiatan untuk peningkatan derajat kesehatan ibu dan anak, serta peningkatan akses pendidikan dasar dan menengah. Sebagai stimulan dalam menyusun perencanan kegiatab yang akan dilakukan, program ini juga menyediakan Bantuan Langsung Masyarakat (BLM) yang dimana memberikan bantuan biaya kepada masyarakat yang kurang mampu yang mempunyai anak yang masih di usia sekolah dasar dan menengah.

Tujuan Program ini adalah

1. Meningkatkanh Derajat Kesehatan Ibu dan anak-anak balita

2. Meningkatnya Pendidikan anak-anak usia sekolah hingga tamat sekolah Dasar (SD/MI) dan Sekolah Lanjutan Tingkat Pertama (SMP/MTs)

Sasaran program adalah anggota masyarakat yang secara rutin dipantau perkembangan atau perolehan layanan bidang kesehatan ibu-anak dan pendidikan dasar. Dengan demikian, sasaran dari program ini adalah seluruh ibuibu yang sedang hamil, ibu menyusui dan bayinya, anak-anak balita, serta anak-anak usia sekolah dasar dan menengah pertama. Penerima manfaat (benecifiary) adalah anggota masyarakat yang menerima manfaat secara langsung dari Bantuan Langsung Masyarakat (BLM). Penerima manfaat Bantuan Langsung Masyarakat (BLM) diutamakan bagi mereka yang termasuk dalam kelompok rumah tangga miskin dan yang selama ini belum mendapatkan pelayanan kesehatan ibu anak dan pendidikan dasar.

\section{Indikator Keberhasilan}

Ukuran atau indikator keberhasilan merupakan kondisional yang akan dicapai oleh masyarakat dan digunakan sebagai dasar untuk menilai keberhasilan dalam rangka mengikuti program ini. Ukuran keberhasilan ini dimaksudkan agar masyarakat memfokuskan pada pencapaian tujuan program dan tidak hanya melakukan kegiatan pendidikan dan kesehatan secara umum. Ukuran yang digunakan adalah sebagai berikut :
1. Bidang Kesehatan, meliputi:

a) Setiap ibu hamil diperiksa oleh bidan, minimal 4 kali pemeriksaan selama masa kehamilannya.

b) Setiap ibu hamil mendapatkan minimal 90 butir pil $\mathrm{Fe}$ (penambah darah) selama masa kehamilannya.

c) Setiap proses kelahiran ditangani oleh tenaga bidan atau dokter

d) Setiap ibu yang melahirkan dan bayinya mendapatkan perawatan nifas oleh bidan atau dokter, minimal 2 kali perawatan dalam waktu 40 hari setelah proses persalinan.

e) Setiap bayi usia 12 bulan ke bawah mendapatkan imunisasi standar secara lengkap

f) Setiap bayi usia 12 bulan ke bawah berat badannya ditimbang dan selalu naik pada setiap bulannya ( untuk bayi di bawah usia 6 bulan, berat badannya naik lebih dari $500 \mathrm{~g}$ per bulan dan bayi usia 6-12 bulan naik lebih dari $300 \mathrm{~g}$ ).

g) Setiap anak usia 6 bulan sampai 59 bulan mendapatkan Vitamin A, 2 kali dalam setahun

h) Setiap anak balita (bawah lima tahun) ditimbang sebulan sekali secara rutin.

2. Bidang Pendidikan, meliputi:

a) Setiap anak usia sekolah dasar (7 tahun ke atas) terdaftar sebagai siswa Sekolah Dasar (SD/MI)

b) Tingkat kehadiran setiap siswa SD/MI dalam mengikuti proses belajar mengajar, minimal $85 \%$. Usia sekolah SD menurut DEPDIKNAS adalah 7 sampai 12 tahun

Pendidikan merupakan hal yang paling penting dalam proses perkembangan individu dan masyarakat, dengan pendidikan manusia bisa merancang sebuah model masa depan yang lebih baik. Masyarakat desa memandang pendidikan merupakan hal yang penting, 
namun ketersediaan sistem sumber yang mendukungnya belum dapat terpenuhi. Terutama untuk masyarakat yang perekonomiannya menengah kebawah. Pendidikan dasar sembilan tahun yang digadang-gadang pemerintah bisa mengatasi masalah pendidikan.

Program ini merupakan bagian dari PNPM Mandiri yang direncanakan akan dilakukan sampai dengan tahun 2015. Pendekatan dalam PNPM Generasi dengan menggunakan dasardasar pemberdayaan masyarakat. Artinya bahwa program ini harus berangkat dari masyarakat, dilakukan oleh masyarakat dan diperuntukkan juga bagi masyarakat. Dibandingkan dengan pendekatan lainnya, pendekatan pemberdayaan masyarakat lebih mampu menjamin efektifitas dan keberlanjutan sebuah program penanggulangan kemiskinan.

Dengan adanya program ini masyarkat bisa berpartisipasi dalam meningkatkan mutu kehidupannya dengan cara berpartisipasi dalam program ini, masyarakat bisa mengoptimalkan aktualisasi dirinya dengan Focus Disscusion Group mereka dapat menemukan jalan keluar bagi masalah yang mereka hadapi.

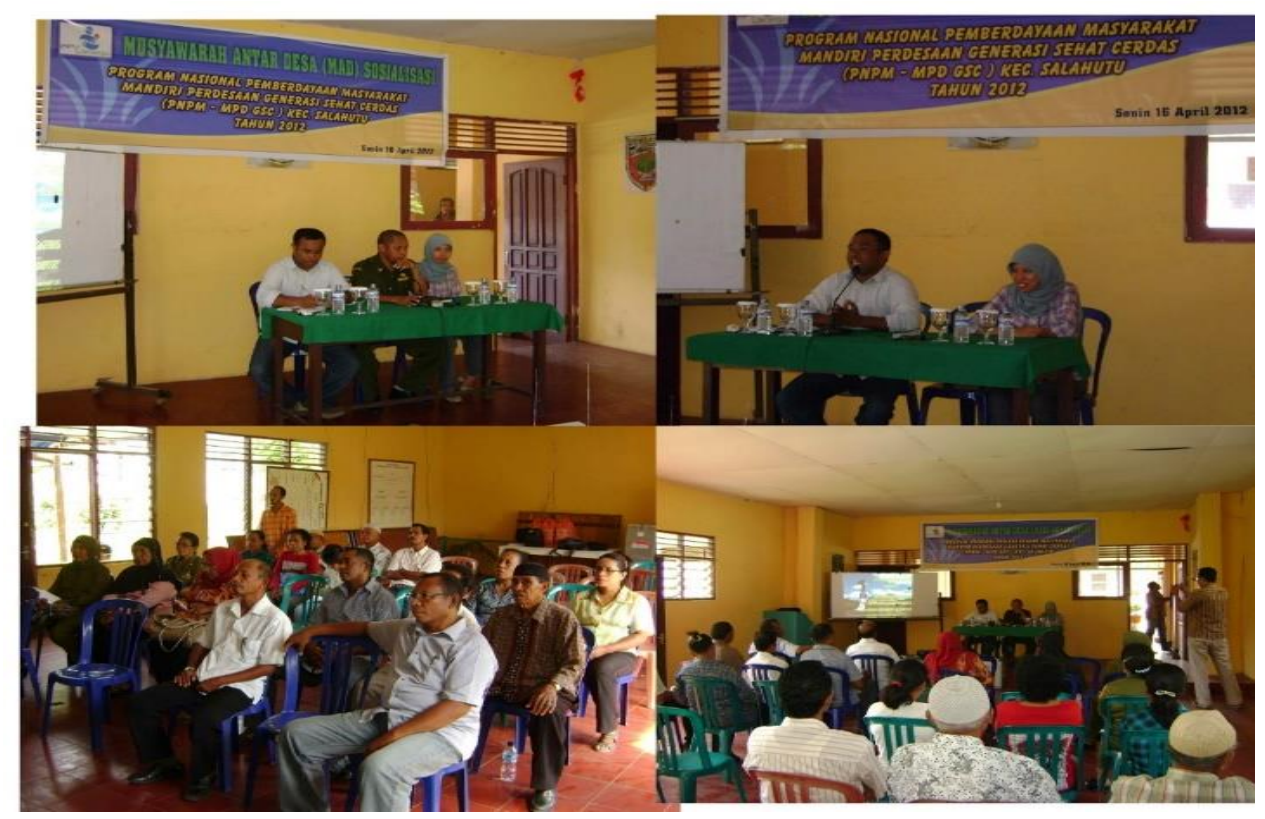

Dari gambar tersebut dapat terlihat masyarakat melakukan musyawarah program generasi sehat cerdas, mereka dengan semangat menyusun rencana strategis agar program ini bisa maksimal, selain program bisa berjalan masyarakat yanbg tergabung dal tim juga mendapatkan pengalaman yang menarik berkecimpung dalam pelaksanaan program yang sekaligus memberikan penilaian dan pengawasan terhadap kebijakan yang sedang berlangsung.

Program yang dilakukan oleh PNPM Mandiri tersebut merupakan salah satu upaya pemerintah untuk meningkatkan pembangunan manusia, yang dimana tidak bisa dipisahkan dengan prinsip pembangunan sosial berkelanjutan. Pembangunan yang dimana mengedepankan kapasitas masyarakat yang memiliki potensi yang bisa dikembangkan baik secara sumber daya manusia maupun peningkatan ekonomi. Midley menemukan 3 Strategi dasar tentang 3 strategi yang dimana strategi tersebut berbanding lurus dengan apa yang ada di konsep pekerjaan sosial dan kesejahteraan sosial. Dimana individu, komunitas dan masyarakat bisa mengembangkan potensipotensi yang ada adalam dirinya sehingga dapat mencapai aktualisasi diri, serta bisa meningkatkan keberfungisan sosialnya. Tiga strategi tersebut meliputi: 
1. Pembangunan Sosial melalui individu (Social Development by Individuals), dimana individu-individu dalam sebuah masyarakat secara swadaya membentuk usaha pelayanan masyarakat guna memberdayakan masyarakat (Community Empowerment)

2. Pembangunan Sosial Melalui Komunitas (Social Development by Communities), yang dimana kelompok masyarakat secara bersama-sama berupaya mengembangkan komunitas lokalnya

3. Pembangunan sosial melalui pemerintah (Social Development by Goverment), dimana pembangunan sosial dilakukan oleh lembagalembaga di dalam organisasi pemerintah. (Midgley 1995:103-138)

Tujuan dari pembangunan sosial adalah pengembangan dan peningkatan kesejahteraan masyarakat (promotion of social welfare). Kesejahteraan sosial yang dimaksudkan midgley adalah kesejahteraan sosial sebagai suatu kondisi sosial dan bukan sekadar kegiatan amal ataupun bantuan sosial yang diberikan oleh pemerintah (1995:13). Kesejahteraan sosial dapat dilihat dari tiga unsur utamanya, yaitu :

a) tingkatan (derajat) sampai dimana permasalahan sosial yang ada di masyarakat dapat dikelola;

b) sampai seberapa banyak kebutuhan masyarakat dapat dipenuhi;

c) sampai seberapa besar kesempatan untuk meningkatkan taraf hidup dapat diperluas pada berbagai lapisan masyarakat (1995:14). Dari hal diatas dapat dilihat bahwa sekarang ini semua pembangunan yang ada di indonesia bertujuan untuk pada akhirnya meningkatkan kesejahteraan sosial masyarakat indonesia, baik dalam hal pendidikan, kesehatan, dan ekonomi.

\section{SIMPULAN DAN SARAN}

Kesimpulannya adalah pengembangan masyarkat yang berbasis partisipasi masyarakat dalam pelaksanaan kebijakan pemerintah, kemudian juga secara tidak langsung memberdayakan masyarakat, sehingga masyarakat bisa terlepas dari ketergantungan terhadap bantuan yang diberikan.

Karakter masyarakat yang masih kurang mengerti dan paham membuat kesadaran masyarakat tentang pentingnya pendidikan berimplikasi terhadap angka partisipasi pendidikan sulit untuk naik. Masyarakat yang sudah terbiasa dengan berbagai program yang sifatnya subsidi membuat masyarakat sulit untuk berkembang, masyarakat mulai berpikir untung rugi untuk menyekolahkan anak-anaknya. Sehingga anak-anak yang kurang mendapat dorongan dari lingkungan sosialnya sehingga memutuskan untuk tidak bersekolah, meskipun secara financial keluarga terlihat cukup. Kemudian selain sudah terbiasa dengan program-program subsidi, tingkat pengetahuan masyarakat akan berbagai program yang disediakan pemerintah seperti beasiswa juga masih kurang. Akaibatnya anak-anak lulusan SMA juga jarang ada yang melanjutkan ke perguruan tinggi, karena pengetahuan tentang informasi program pemerintah juga kurang.Karena saat ini pembangunan bukan hanya sekedar fisik belaka, namun pembangunan yang berbasis kepada manusia sebagai pusat pembangunan, pembangunan mental dan mindset masyarakat yang harus diperhatikan. Karena masyarkat bukan lagi penonton dari pembangunan yang ada, namun jadi bagian yang paling penting agar dapat mencapai kondisi kesejahteraan sosial yang seimbang. pemerintah selaku pemegang regulasi kebijakan yang mengayomi rakyatnya telah menggulirkan berbagai program propendidikan diantaranya program wajar dikdas 9 tahun yang sekarang sedang diusahakan oleh pemerintah Jawa Barat menjadi 12 tahun, Generasi Sehat Cerdas dari PNPM dan program-program beasiswa lainnya yang 
semuanya ditujukan untuk mewujudkan kehidupan masyarakat dan pemerataan pendidikan masyarakatnya.

Dengan menganalisis kebutuhan dimasyarakat di bidang pendidikan, peran pemerintah sangat penting dalam distribusi informasi tentang pendidikan kepada masyarakat, agar bisa meningkatkan partisipasi masyarakat. Kemudian para stakeholder yang terkait dibidang pendidikan bisa memanfaatkan teknologi informasi sebagai kebutuhan yang bisa dimanfaatkan secara positif oleh anak-anak yang masih berada dalam usia sekolah, sehingga mereka bisa mengakses informasi tentang beasiswa, bantuan pemerintah seperti BSM dan KIS.

Tidak lupa juga peran orangtua sangat penting untuk mendukung anak-anaknya untuk bersekolah, karena pemerintah juga telah menyiapkan wajib belajar 12 tahun yang bisa dimanfaatkan secara maksimal. Orang tua juga bisa mendapatkan layanan informasi tentang pendidikan untuk anak-anaknya agar mereka termotivasi untuk bersemangat sekolah.

\section{DAFTAR PUSTAKA}

$\begin{array}{rrrr}\text { Isbandi } & \text { Rukminto } & \text { Adi. } & \text { 2012. Intervensi } \\ \text { Komunitas } & \& & \text { Pengembangan }\end{array}$
Masyarakat Sebagai Upaya Pemberdayaan. Jakarta : PT Raja Grafindo Persada.

Abu Huraerah. 2003. Isu Kesejahteraan Sosial (Di Tengah Ketidakpastian Indonesia). Bandung: CEPLAS (Center for Political and Local Autonomy Studies)

Suharto, Edi. 2013. Kebijakan Sosial Sebagai Kebijakan Publik. Bandung: Afabeta. Cetakan ke-empat

Santoso T. Raharjo. 2014. Dasar Pengetahuan Pekerjaan Sosial. Sumedang: Unpad Press

Budhi Wibawa, Santoso T. Raharjo dan Meilany Budiarti S. 2010. Dasardasar Pekerjaan Sosial. Bandung: Widya Padjadjaran

Bungin, Burhan. 2005. Metodologi Penelitian Kuantitatif. Jakarta: Kencana Prenada Group (Edisi Kedua)

Ndraha, Taliziduhu. 1990. Pembangunan Masyarakat. Rineka Cipta. Jakarta

Rahardjo, M. Dawan. 2006. Menuju Indonesia Sejahtera: Upaya Konkret Pengentasan Kemiskinan. Jakarta: Khanata, Pustaka LP3ES Indonesia 